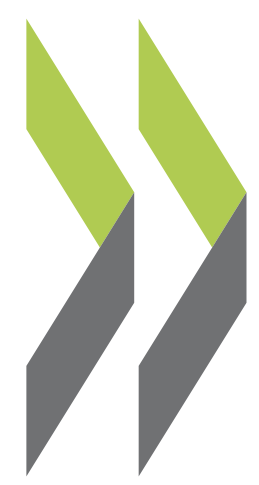

OECD Economics Department Working Papers No. 511 Removing Obstacles to Employment for Women Boris Cournède in Ireland 
Organisation de Coopération et de Développement Economiques

ECONOMICS DEPARTMENT

English text only

REMOVING OBSTACLES TO EMPLOYMENT FOR WOMEN IN IRELAND

ECONOMICS DEPARTMENT WORKING PAPERS No. 511

By

Boris Cournède

All Economics Department Working Papers are available through OECD's Internet website at www.oecd.org/eco/Working_Papers. 


\section{Abstract \\ Removing obstacles to employment for women in Ireland}

Women have contributed a great deal to Ireland's economic growth, including by joining the labour force in large numbers. The rise in female participation since 1990 has been amongst the strongest in the OECD, but from a low base. Female participation rates remain below the OECD average for all except the under-thirties. Cultural attitudes and low educational attainment among older women are factors, but policy settings play a role as well. Support to families is not targeted at working parents, implying that the return to work is low for many mothers. Working parents of school-age children also face difficulties in reconciling employment and work because out-of-school care is insufficiently developed. The tax system should be further improved to support second earners, most of whom are women, so as to strengthen their incentive to enter the labour market and reduce the bias in favour of the home production of services such as childcare. This paper reviews these issues and offers recommendations to continue to create a more favourable environment for women who want to enter the labour market.

This paper relates to the 2006 Economic Survey of Ireland (www.oecd.org/eco/surveys/ireland).

JEL classification: D13; J16; J21; J22.

Key words: Efficiency; Optimal Taxation; Fiscal Policies; Behaviour of Households; Government Expenditures; Child Care; Economics of Gender; Labour Force; Employment, Size; Structure; Time Allocation; Labour Supply.

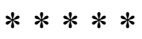

\section{Résumé}

\section{Éliminer les obstacles à l'emploi des femmes en Irlande}

Les femmes ont largement contribué à la croissance économique de l'Irlande, notamment en rejoignant le marché du travail en grand nombre. L'augmentation du taux de participation des femmes depuis 1990 a été l'une des plus fortes enregistrées au sein de l'OCDE, mais à partir d'un faible niveau initial. Les taux de participation des femmes demeurent en dessous de la moyenne de l'OCDE sauf pour les moins de trente ans. Des facteurs culturels ainsi que le faible niveau moyen d'étude des femmes âgées peuvent expliquer en partie cette situation, mais le cadre d'action publique joue également un rôle. Comme les prestations familiales ne sont pas ciblées sur les parents qui travaillent, peu de mères reviennent à la vie active. Pour les parents d'enfants d'âge scolaire, il n'est pas non plus aisé de concilier travail et vie de famille car les services de garde extrascolaire ne sont pas assez développés. Enfin, le système fiscal devrait être amélioré pour aider le second apporteur de revenu, c'est-à-dire le plus souvent la femme, en l'incitant davantage à prendre un emploi rémunéré et en réduisant le biais en faveur de la production de services au sein du ménage tels que la garde d'enfants. La présente étude s'intéresse à ces différentes questions avant de formuler une série de recommandations qui visent à poursuivre la mise en place d'un environnement plus favorable pour les femmes qui souhaitent travailler.

Ce document se rapporte à l'Étude économique de l'Irlande 2006 (www.oecd.org/eco/etudes/irlande).

Classification JEL : D13; J16; J21; J22.

Mots clés : efficience; taxation optimale; politiques publiques ; comportement des ménages ; dépenses publiques; garde d'enfants; économie de l'égalité des sexes; force de travail; emploi ; taille ; structure ; allocation du temps ; offre de travail.

\section{Copyright OECD, 2006}

Application for permission to reproduce or translate all, or part of, this material should be made to: Head of Publications Service, OECD, 2 rue André Pascal, 75775 Paris Cedex 16, France. 


\section{TABLE OF CONTENTS}

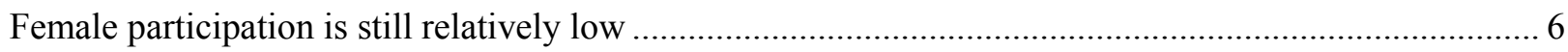

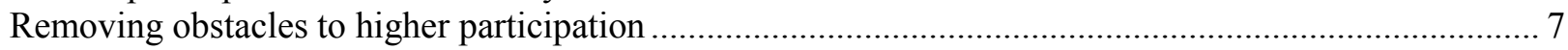

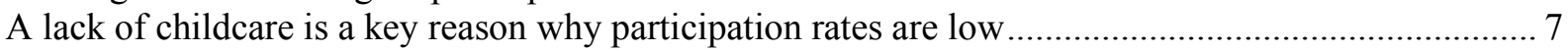

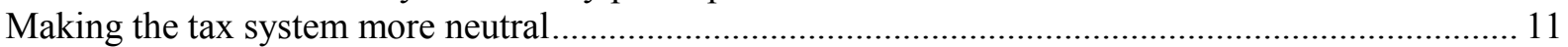

Reforming the childcare sector and the tax and benefit system in tandem..................................... 13

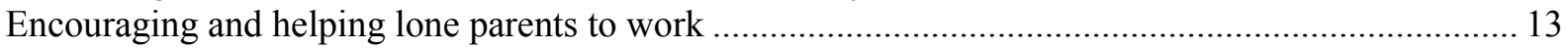

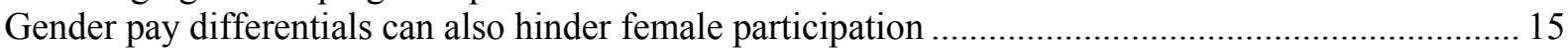

Recommendations for sustaining growth in women's labour force participation................................... 15

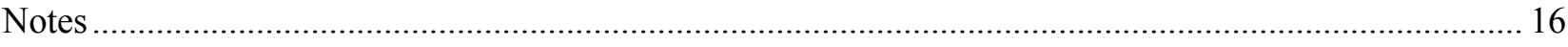

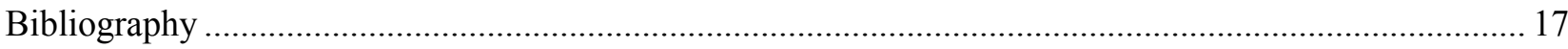

Box

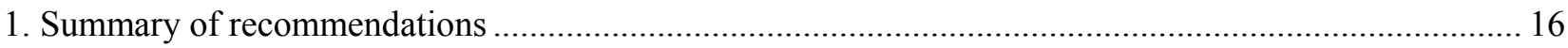

\section{Tables}

1. Taxes and childcare costs absorb most of working mothers' income ........................................... 7

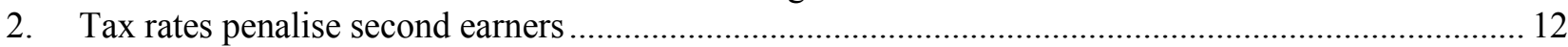

\section{Figures}

1. Female participation has risen a lot but is still low......................................................................... 5

2. Young women's participation is below OECD best performance..................................................... 6

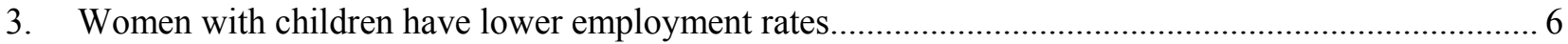

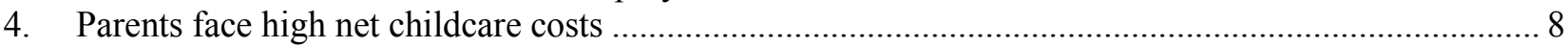

5. Benefits and tax create a low activity trap for lone parents .............................................................. 14 


\section{ECO/WKP(2006)39}




\title{
Removing obstacles to employment for women in Ireland
}

\author{
by Boris Cournède ${ }^{1}$
}

The boom in the Irish economy owes a lot to women, who have entered the labour market in large numbers. Indeed, women account for more than nine tenths of the increase in labour force participation since 1990, and the Celtic Tiger has been described as the Celtic Tigress (O'Connor, 1998). But even though the rise in female participation since 1990 has been among the strongest in the OECD, it was rising from such a low level that the participation rate is still a little below the OECD average (Figure 1). Maintaining rapid income growth into the future will require further efforts to remove barriers and disincentives to work for those women who choose to combine bringing up children and pursuing a career. Changes implemented in recent years have reduced the extent to which the tax and welfare systems are geared towards traditional single-breadwinner families. Nonetheless, there is still scope for further progress to create an environment that enables families to make their own choices about the right balance between work and family life.

Figure 1. Female participation has risen a lot but is still low

Percentage of women aged 15-64 in the labour force
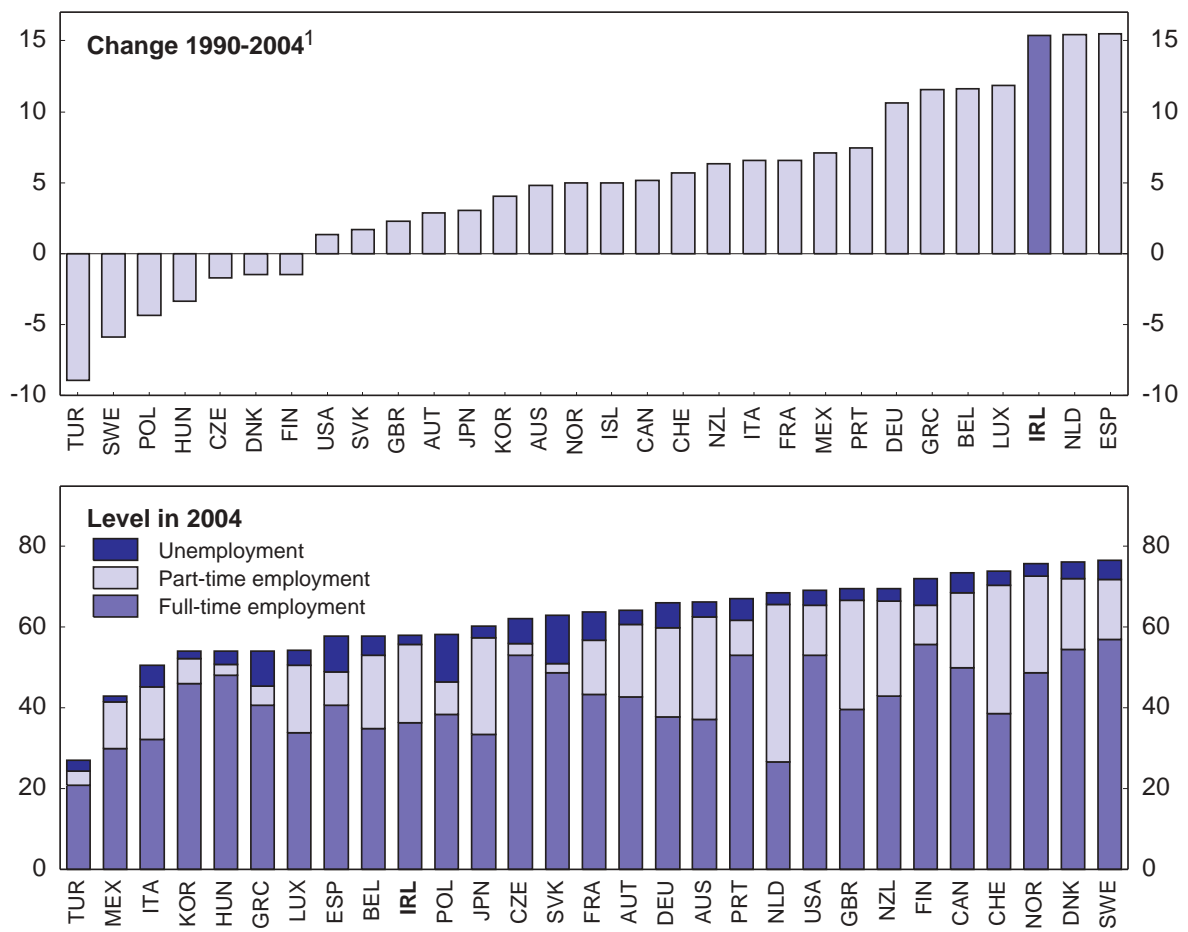

1. 1991 for Iceland, Mexico and Switzerland; 1992 for Hungary and Poland; 1993 for Czech Republic; 1994 for Austria and Slovak Republic.

Source: OECD database on Labour Force Statistics, January 2006.

1. This paper was originally prepared for the OECD Economic Survey of Ireland published in March 2006 on the responsibility of the Economic and Development Review Committee. Thanks are due to experts from the Irish Department of Finance. The author would also like to thank colleagues in the OECD, especially Willem Adema, Andrew Dean, Peter Hoeller, Val Koromzay and Dave Rae for their helpful comments. Special thanks go to Desney Erb for technical assistance and to Sara Crohem and Celia Rutkoski for technical preparation. The author can be contacted at boris.cournede@oecd.org. 


\section{Female participation is still relatively low}

Young women are much more likely than their mothers to be working or looking for a job. The participation rate of younger women (those aged 25 to 34) has increased from $30 \%$ in 1975 to $76 \%$ in 2004. In contrast, only a third of women aged 55 to 64 have a job, not only because of social attitudes but also because their education levels are comparatively poor. Even so, participation by the younger cohorts is still below the OECD average and around 13 percentage points below the best performing countries (Figure 2).

Figure 2. Young women's participation is below OECD best performance Female labour force in per cent of population, age group 25-34

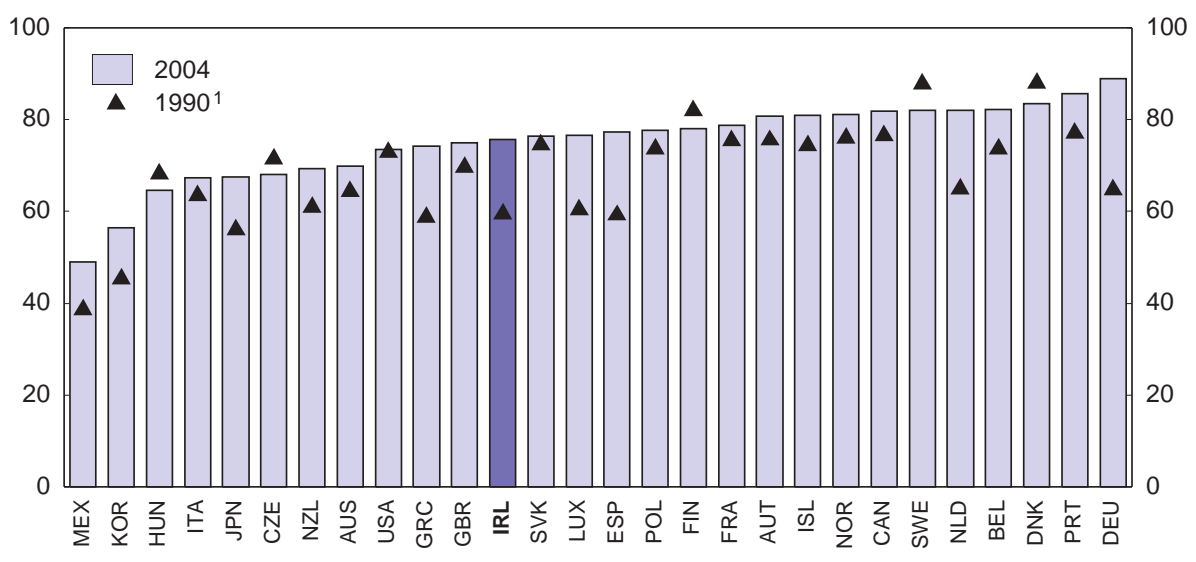

1. 1991 for Iceland and Mexico; 1992 for Hungary and Poland; 1993 for Czech Republic; 1994 for Austria and Slovak Republic.

Source: OECD database on Labour Force Statistics, January 2006.

In addition, there is a striking difference in labour market participation between women with and without children. Among women aged 25-54 who have two or more children below age 16, the full-time employment rate is only $22 \%$ - one of the lowest in the OECD and well below the $59 \%$ average among the Nordic countries (Figure 3). Effective labour supply is even lower than these figures suggest since about half of those who work do so part time, which is one of the highest incidences of part-time work in the OECD.

Figure 3. Women with children have lower employment rates ${ }^{1}$

Persons aged 25 to 54 years, 2000

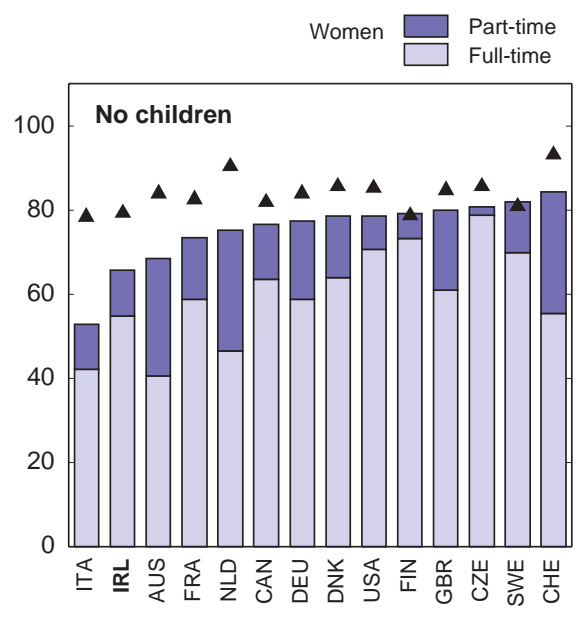

$\Delta$ Men

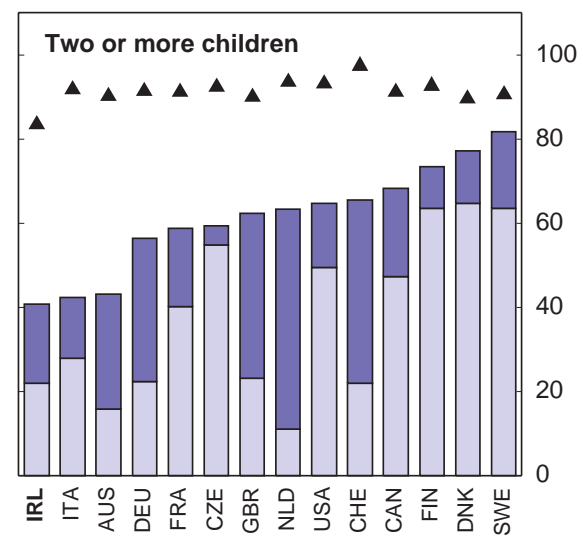

1. Children aged under 15 (16 for Sweden).

Source: OECD (2002), Employment Outlook, Paris. 
One reason for taking policy action is the risk that the higher participation of young women could actually go into reverse as generations are renewed. Despite the combination of relatively high tax rates on second earners and limited support for childcare (see below), many of the young mothers who have been able to work can do so because they can rely on free or low-cost help from older women, friends or relatives who are not working (OECD, 2003a). The supply of such helpers may dry up as today's young female cohorts grow older.

\section{Removing obstacles to higher participation}

Many mothers choose to work part-time. One reason is that when a mother takes up a full-time job, childcare costs and additional taxes paid by the household absorb a substantial share of her income. Table 1 shows that, in typical situations and using national averages, effective tax rates on full-time work, when combined with childcare costs, reach $65 \%$ or more. Effective tax rates are even higher in Dublin, where day care is about $50 \%$ more expensive than elsewhere. For a Dublin-based family with two young children where one spouse works and earns the average production wage (APW), there is little point for the other spouse to take up a job paid at two-thirds of the APW: the effective "tax plus childcare" rate is $93 \%$ (against $82 \%$ as shown in Table 1 if the same family had access to childcare at a cost equal to the national average).

Table 1. Taxes and childcare costs absorb most of working mothers' income

Childcare costs and tax dues as a percentage of the income of the second earner, $2002^{1}$

\begin{tabular}{lccc}
\hline Level of income of the second earner $^{2}$ & $33 \%$ & $67 \%$ & $100 \%$ \\
\hline Young children $^{3}$ & 64 & 82 & 65 \\
School-age children & 21 & 65 & 54 \\
\hline
\end{tabular}

1. The first earner is paid the average production wage (APW). In the situation where the earnings are $33 \%$ of the APW, the second earner works part-time and takes care of the children during the rest of the working day. In the two other situations, both parents work full-time and must pay for full-time childcare and/or out-of-school care depending on the age of the children.

2. As a per cent of the APW.

3. Aged 1 and 4 , the older child is in infant class.

Source: OECD (2003), Babies and Bosses: Reconciling Work and Family Life, Vol. 2, OECD, Paris.

\section{A lack of childcare is a key reason why participation rates are low}

In international comparison, public spending on childcare was very low in Ireland until recently, and as a result parents face the highest level of net childcare costs among OECD countries (Figure 4). Only $12 \%$ of children under age three are in registered childcare against an OECD average of $29 \%$ and rates reaching 54\% and 65\% in the United States and Sweden (Immervoll and Barber, 2005). As female participation rises further and informal carers such as non-working mothers and sisters become harder to find, affordable childcare becomes increasingly important for female participation. The Budget 2006 set out an investment programme targeting an extra 50000 childcare places by 2010 (one additional place per five children below age four). When implemented in full, this programme will bring the coverage rate of non-parental childcare services close to the current OECD average and should facilitate the work decision of many mothers. A difficulty, however, is the absence of clear rules giving priority access to community childcare to those most needing it (OECD, 2003a). Existing places should be allocated in priority to children whose parents are both at work. 
Figure 4. Parents face high net childcare costs

$2001^{1}$
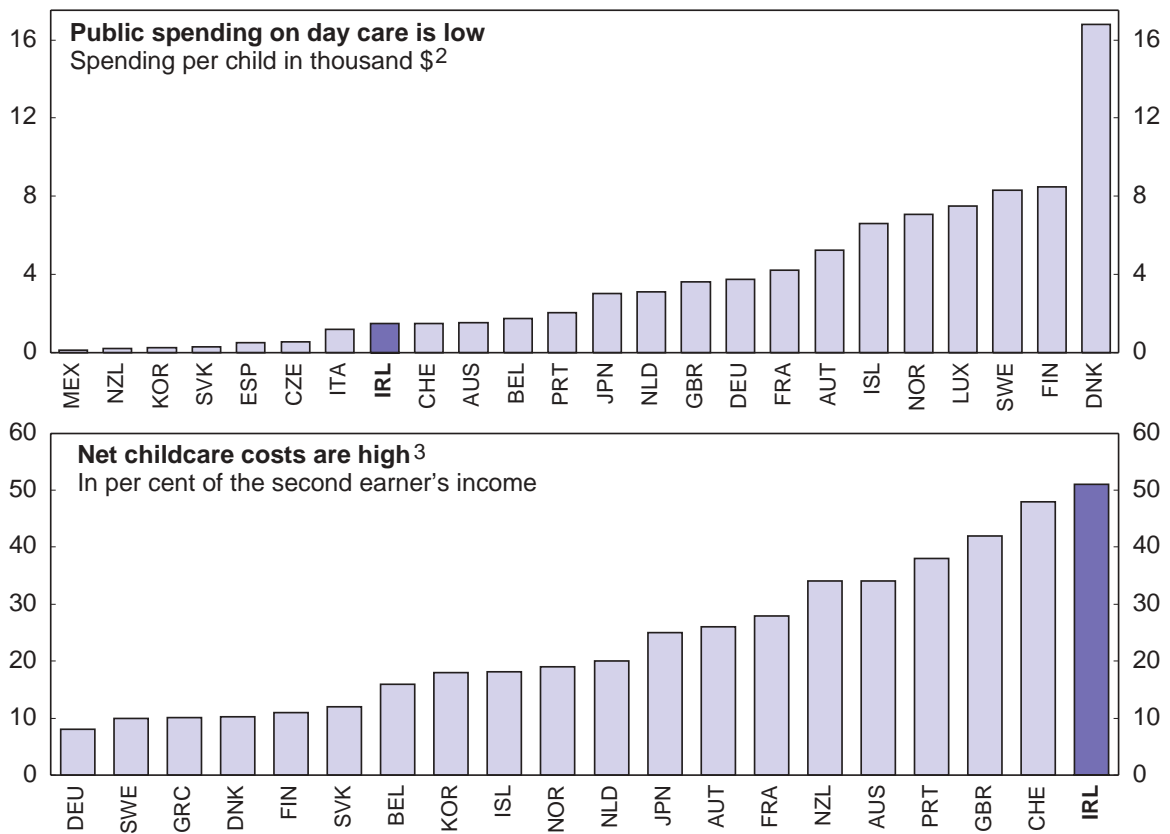

1. While results relate to the latest year for which the necessary data is available (2001 unless otherwise mentioned), the situation has changed since then, particularly in Ireland where the 2006 Budget included significant increases in public expenditure on the supply of day care from 2006 onwards.

2. Public spending on non-parental day care for children aged under 3 years old. At current prices and purchasing power parities.

3. Each parent earns the average production wage and they have two children, aged 2 and 3. Results for Belgium, France, New Zealand, Sweden, United Kingdom and United States relate to 2002.

Source: OECD (2005), Social Expenditure database; OECD (2005), Education at a Glance; Immervoll, H. and D. Barber (2005), "Can Parents Afford to Work? Childcare costs, Tax-benefit Policies and Work Incentives", OECD Social, Employment and Migration Working Papers, No. 31.

Mothers still encounter difficulties in reconciling work and family life when their babies grow older. Public supply of pre-primary education is limited: so-called infant classes enrol only half of children aged 4-6 and only for half the day. Access to schooling is universal from age five, but the difficulty for parents is a lack of after-school care: only $2.2 \%$ of primary school pupils were enrolled in after-school programmes in 2002 (CSO, 2003). Primary schools provide very little extended care: only $1.2 \%$ of all 6-12 year olds used this form of provision in 1999-2000 (National Women's Council of Ireland, 2005). As the number of children is declining with demographic change, capacity is becoming available in schools, but school boards have been reluctant to open up their facilities to provide extended care or to make them available to other providers. On-premises extended care is an economically sensible use of available capacity as well as a favourable option for children who are spared being transported from the school to the after-school facility. The package announced in the 2006 Budget included an initiative to increase the supply of out-ofschool-hours care by 5000 places (which corresponds to $1.3 \%$ of the population aged 6-12) by 2010 . 
ECO/WKP(2006)39

\section{Family support measures are not targeted on childcare}

The main measure to help parents and encourage fertility - the Child Benefit - does not create an incentive for parents to work. The Child Benefit is a cash transfer that depends solely on the number of children. It comes with no employment condition or job search requirement. After several rounds of increases in the recent past, it now absorbs $1 \frac{1}{2}$ per cent of national income. The Child Benefit is relatively high by international standards: it raises the disposable income of a typical family by $10 \%$, against an OECD average of $7 \frac{1}{2}$ per cent. ${ }^{1}$

The Early Childcare Supplement introduced by the 2006 Budget is also a cash transfer that is paid to parents regardless of their labour force status and is not tied to the purchase of childminding services. Effective from the second quarter of 2006, this payment of $€ 1000$ per year for each child under age six will add 5\% to the disposable income of a typical family with two young children. ${ }^{2}$ Even though the new benefit increases beneficiaries' income, it does not reduce the net childcare costs that a previously nonworking spouse faces when she takes up market work. Because it has not been made conditional on the purchase of childcare services or on both parents working, the Early Childcare Supplement is a missed opportunity to help families face the costs of childcare while encouraging female labour force participation.

Another family support measure, the home carer tax credit, is a direct subsidy to staying at home and should be phased out. A rebate of $€ 770$ on the household's tax bill for income earned in a tax year, the home carer tax credit is deducted from the tax bill of families where one spouse cares for the children at home. Eligibility to the tax credit is compatible with only a very limited degree of activity in the labour market: the credit is phased out between $18 \%$ and $23 \%$ of the average production wage. The impact of the home carer tax credit is not negligible: it adds 3\% to the disposable income of a family where the one working spouse earns the average production wage. The cost of this tax relief amounted to an estimated $€ 94$ million ( $0.2 \%$ of government receipts) in 2005 (McCreevy, 2004). While the home carer tax credit contains provisions aimed at easing the transition to work such as an income disregard and a taper, their effect is limited since the tax credit is lost in full as soon as income exceeds $22 \%$ of the average production wage.

\section{More focus on childcare is warranted}

There are good reasons for the government to subsidise part of childcare costs. First, early childhood care and education has positive spillover effects on the performance of children in their further education and socialisation, though the evidence is less clear for children below the age of one. ${ }^{3}$ This would be especially beneficial for the integration of children of immigrants. Second, childcare subsidies reduce the effective tax rate on mothers. Third, childcare subsidies for low-income mothers may allow them to break away from welfare dependence, generating savings in welfare spending for the government. More generally, increased female participation, especially in full-time jobs, would reduce precariousness of women and children in cases of marital separation and promote gender equity. However, not all of childcare provision should be financed publicly because this could quickly lead to cost inflation in provision, as is illustrated by the example of Denmark where public spending on day care has reached $1.7 \%$ of GDP. The way subsidies are provided should also provide incentives to choose childcare in a cost conscious way. Schemes that offer a certain amount of assistance and maintain an incentive at the margin should be preferred to alternatives where parents get refunded for the full cost of childcare they have incurred. 
From a labour supply point of view, resources should over time become focused on parents who work or use childcare services. Paying childcare supports such as the Early Childcare Supplement only to families which use childcare services and where both parents are in employment (or actively looking for a job) would boost the labour supply by mothers and could at the same time provide an incentive for parents to choose childcare in a cost-conscious manner. A conditional benefit of this nature would provide resources to working parents and help them to pay for childcare while bringing more of the childcare sector in the formal economy. An important proviso is that the payment should be determined ex ante and not calculated ex post to cover the amount parents have spent on childcare, so that they have an incentive to shop around for good, but low-cost childcare.

A reform along those lines was considered and rejected in 2004 and instead the government chose to increase the Child Benefit substantially (Tax Strategy Group, 2004). An important principle determining policy in this area is the belief that mothers at home should not be discriminated against. Again in 2005, the authorities decided against making the Early Childcare Supplement conditional on parents being in the labour force. However, it needs to be recognised that support for working families is not discriminating in their favour, it is just trying to counteract the bias against them that is created by other parts of the tax system (notably, that care at home is not taxed while paid childcare is taxed) - i.e. it is attempting to create a level playing field. It should also be recognised that encouraging women's participation in the labour force will require creating rewards for dual income couples and that this cannot be done under the constraint that the relative financial position of one-income families be untouched.

There is also a concern that demand-side measures might just push up the price of childcare and ultimately do little to help parents. If measures supporting the purchase of childcare services were to be introduced suddenly and at high levels, such a risk could materialise for a limited period: prices would rise until supply has adjusted to the increased level of demand. However, especially given that the construction of childcare facilities receives favourable treatment in the planning process and gives rise to generous tax breaks for developers, there is little reason to fear that supply would not adjust over the medium term. In short, the concern over price inflation in the sector is no justification for a pure supply-side strategy but calls for ensuring that any increase in demand-side support be gradual.

Support to the supply of childcare appears least attractive and should be only temporary. The childcare package announced in the 2006 Budget foresees the government financing the supply of childcare facilities. The main rationale behind this approach lies in the observation of shortages in the supply of affordable childcare services. However, it is not obvious how much of the problem reflects issues of affordability (i.e. something that should be dealt with on the demand side) or supply. Indeed, generous "brick and mortar" tax breaks were already available for the construction of childcare facilities, even though the main supply bottleneck appears to be a shortage of training for qualified staff - there are more women who want to become qualified childminders than there are training places in educational institutions. Current plans to increase the number of training places, as announced in the 2006 Budget, are welcome and should be implemented swiftly. 
ECO/WKP(2006)39

\section{Making the tax system more neutral}

Alongside the lack of childcare support, the tax system discourages married women from joining the labour force because it imposes a higher burden on second earners than on single persons and first earners. A one-income married couple with no children where the husband earns the average wage pays $9 \frac{1}{2}$ per cent of its income in income tax and social security contributions. If the wife takes up a job paying two-thirds of the average wage, the additional amount of income tax and social security contributions paid by the household will absorb $17 \%$ of her earnings: in other words, she faces an effective tax rate of $17 \%$. If the same woman earned the same wage but were single, her effective tax rate would only be $9 \%$. The main reason for the difference in effective tax rates is that one-income married couples get a much higher tax allowance than single persons.

Even though they have been reduced significantly over recent years, the marginal tax rates on second earners (alongside the lack of childcare) may explain why women work comparatively short weeks in Ireland. At 31.4 hours, the number of hours worked per employed woman is well below the OECD average of 35.4. Over a sizeable part of the wage distribution, the tax system imposes high marginal tax rates on second earners, creating a disincentive for them to increase their numbers of hours worked. For instance, for a second earner married to someone earning $133 \%$ of the average production wage, the higher rate of income tax (42\%) kicks in at just $76 \%$ of the average wage. Adding social contributions, a person in this situation faces a marginal effective tax rate of $48 \%$ on every extra hour worked. In contrast, a single person pays the higher rate of income tax on an additional hour of work only when their income exceeds the average production wage. ${ }^{4}$ Moving to individual taxation offers a practical way of reducing the number of second earners who face marginal effective tax rates of $48 \%$. Such a change would boost labour supply by increasing the return to working longer for many women who currently work part-time.

International evidence shows that income tax can act as a particularly strong disincentive to take up paid work for married women. When deciding whether and for how many hours to join the labour market, married women, because of their traditional role in (untaxed) home production, are typically found to be more influenced by the after-tax wage than men and single women (Jaumotte, 2003). A consequence is that the distortionary effect of income tax on the labour supply decision will be higher for married women than for others: theory even suggests that an optimal tax system should tax their income at a lower rate (OECD, 2005). For mothers, the impact of taxes is compounded by the cost of childcare.

In international comparison, while Ireland has one of the lowest tax rates on single persons and oneincome families, the effective tax rate on second earners is closer to (but still below) the OECD median (Table 2). Because it reduces the need for additional earnings, the low average tax rate makes non-working spouses in one-income couples more sensitive to their effective marginal rates when they ponder entering the labour force. In other words, the low average rate of taxation implies a weak income effect, and gives more importance to the substitution effect in the work decision of prospective second earners (Smith et al., 2003). 
Table 2. Tax rates penalise second earners ${ }^{1}$

Per cent, latest available year

\begin{tabular}{|c|c|c|c|c|}
\hline & \multicolumn{3}{|c|}{$\begin{array}{l}\text { Women earning two-thirds } \\
\text { of the average production wage }\end{array}$} & \multirow{2}{*}{$\begin{array}{c}\text { One-income } \\
\text { married couple } \\
\text { earning the } \\
\text { average production } \\
\text { wage }\end{array}$} \\
\hline & $\begin{array}{l}\text { Second } \\
\text { earner }\end{array}$ & Single & Difference & \\
\hline Ireland & 24 & 15 & 9 & 7 \\
\hline Australia & 26 & 20 & 6 & 24 \\
\hline Austria & 25 & 23 & 2 & 26 \\
\hline Canada & 31 & 19 & 12 & 21 \\
\hline Czech Republic & 42 & 21 & 21 & 18 \\
\hline Denmark & 48 & 39 & 9 & 36 \\
\hline Finland & 25 & 25 & 0 & 30 \\
\hline France & 24 & 20 & 4 & 21 \\
\hline Germany & 51 & 35 & 16 & 18 \\
\hline Greece & 16 & 16 & 0 & 17 \\
\hline Hungary & 18 & 18 & 0 & 18 \\
\hline Iceland & 44 & 20 & 24 & 14 \\
\hline Italy & 32 & 22 & 10 & 21 \\
\hline Japan & 20 & 17 & 3 & 14 \\
\hline Korea & 8 & 8 & 0 & 8 \\
\hline Netherlands & 35 & 28 & 7 & 29 \\
\hline New Zealand & 20 & 19 & 1 & 21 \\
\hline Norway & 30 & 25 & 5 & 26 \\
\hline Poland & 39 & 30 & 9 & 30 \\
\hline Portugal & 17 & 13 & 4 & 11 \\
\hline Slovak Republic & 25 & 18 & 7 & 8 \\
\hline Spain & 21 & 13 & 8 & 11 \\
\hline Sweden & 28 & 28 & 0 & 31 \\
\hline Switzerland & 23 & 18 & 5 & 16 \\
\hline Turkey & 28 & 28 & 0 & 30 \\
\hline United Kingdom & 27 & 20 & 7 & 17 \\
\hline United States & 30 & 22 & 8 & 10 \\
\hline OECD median & 26 & 20 & 6 & 18 \\
\hline
\end{tabular}

1 The relevant effective tax rate for a married woman's decision to participate or not in the labour market is the average tax rate on the second earner's earnings, defined as the proportion of these earnings that goes into paying increased household taxes. The husband earns $100 \%$ of Average Production Worker earnings (APW), and the couple has two children. In other words, the effective tax rate on a second earner is equal to the difference between the tax due by a " $(100 \%+67 \%)^{\star} \mathrm{APW}$ " household and a " $(100 \%+0 \%)^{\star} A P W "$ household, as a ratio to the second earner's income $(67 \%$ of APW). This tax rate is compared to the average tax rate for a single individual without children and a two-child, one-income family, both earning the average production wage. The tax rates include employee social security contributions and are net of universal cash benefits. They do not include employer social security contributions, indirect taxes, nor means-tested benefits (except child benefits that vary with income).

2. The rates are calculated with the rules applying to income earned in year 2006 in the case of Ireland. For other countries, the reference year is 2004 for the effective tax rate on one-income couples and 2003 for second earners and singles.

Source: OECD (2005), Going for Growth, Economic Policy Reforms; OECD (2004), Taxing Wages and OECD calculations. 
ECO/WKP(2006)39

\section{Reforming the childcare sector and the tax and benefit system in tandem}

More public funding for childcare is warranted to help more women enter the workforce, but it should not crowd out efforts to reduce the tax burden on second earners. Experience in OECD countries suggests that a neutral tax system is more effective than childcare subsidies in increasing female participation because it benefits more women (i.e. more than just those with young children) and public childcare support substitutes in part for privately paid childcare (Jaumotte, 2003). OECD (2005) estimates suggest that even a fivefold increase in public spending on childcare per child would raise female participation by just 1.4 percentage points. The same study estimated that if the effective tax rates on second earners and single persons were made equal, as is already the case in a large number of OECD countries (Finland, Greece, Hungary, Korea, Luxembourg, Mexico, Sweden and Turkey), the participation rate could rise ten times as much.

Nonetheless, the experience of countries such as Finland, France and Sweden suggests that narrowing the tax difference between first and second earners works best as a complement to supporting day and outof-school care. When only one of the policy levers is used, progress can be difficult or very costly. Without more public funding for childcare, the female participation rate can remain low even when first and second earners face identical effective tax rates as is the situation in Korea and Mexico. In Denmark, where second earners face high effective tax rates, female participation is strong but comes at the cost of very high levels of public spending on childcare (expenditure per child is four times as high as the OECD average).

A joint approach, combining a reduced effective tax rate on second earners (on average and at the margin) and assistance to the purchase of childcare, appears warranted. Moving towards more tax neutrality is desirable but cannot remove the distortion entirely: mothers cannot realistically be taxed for caring for children at home, and exempting working mothers from income tax altogether would raise serious issues of equity across households. In this regard, childcare subsidies (if they are effectively tied to the use of childcare) offer a second-best, indirect way of making market work more attractive when compared with producing childcare services at home (OECD, 2005). Helping parents to work can also reduce the loss of skills that can result from a long period out of work. Russell et al. (2002) followed a group of women who were in full-time home duties in 1994, $90 \%$ of them having been so for more than two years, and observed their labour force status in 1999. They found that those returning to employment experienced significant occupational downgrading. Only 10\% of those who returned found white-collar jobs, while $24 \%$ of them had been in such occupations before leaving the labour force. Furthermore, $64 \%$ of them worked in personal service jobs (shop assistant, waitress, housekeeping, childminding, etc.) even though only half of them had been in this occupational group before.

\section{Encouraging and helping lone parents to work}

Sole parent families are a particular issue in Ireland. One fifth of households with children are single parent families (CSO, 2002), a proportion that is much higher than in most OECD countries. Moreover, the employment rate among sole parent families is relatively low at $39 \%$. This has obvious economic costs, but far more important are the social costs associated with child poverty, which has abated in the Irish society during the Celtic Tiger years but has at the same time become more concentrated in lone parent families (Whelan et al., 2005). By far the most effective way of reducing child poverty is to ensure that parents are in work. The design of the social assistance system does not help in this respect. At around a third of the average wage for a two-child family, the One Parent Family Benefit provides only a minimal level of income support. Furthermore, as in many countries (Figure 5), social assistance to lone parents creates an unemployment trap: lone parents moving from inactivity to a part-time job face a marginal effective tax rate of $52 \%$. 
Figure 5. Benefits and tax create a low activity trap for lone parents

Effective tax rates on lone parents with two children, $2002^{1}$
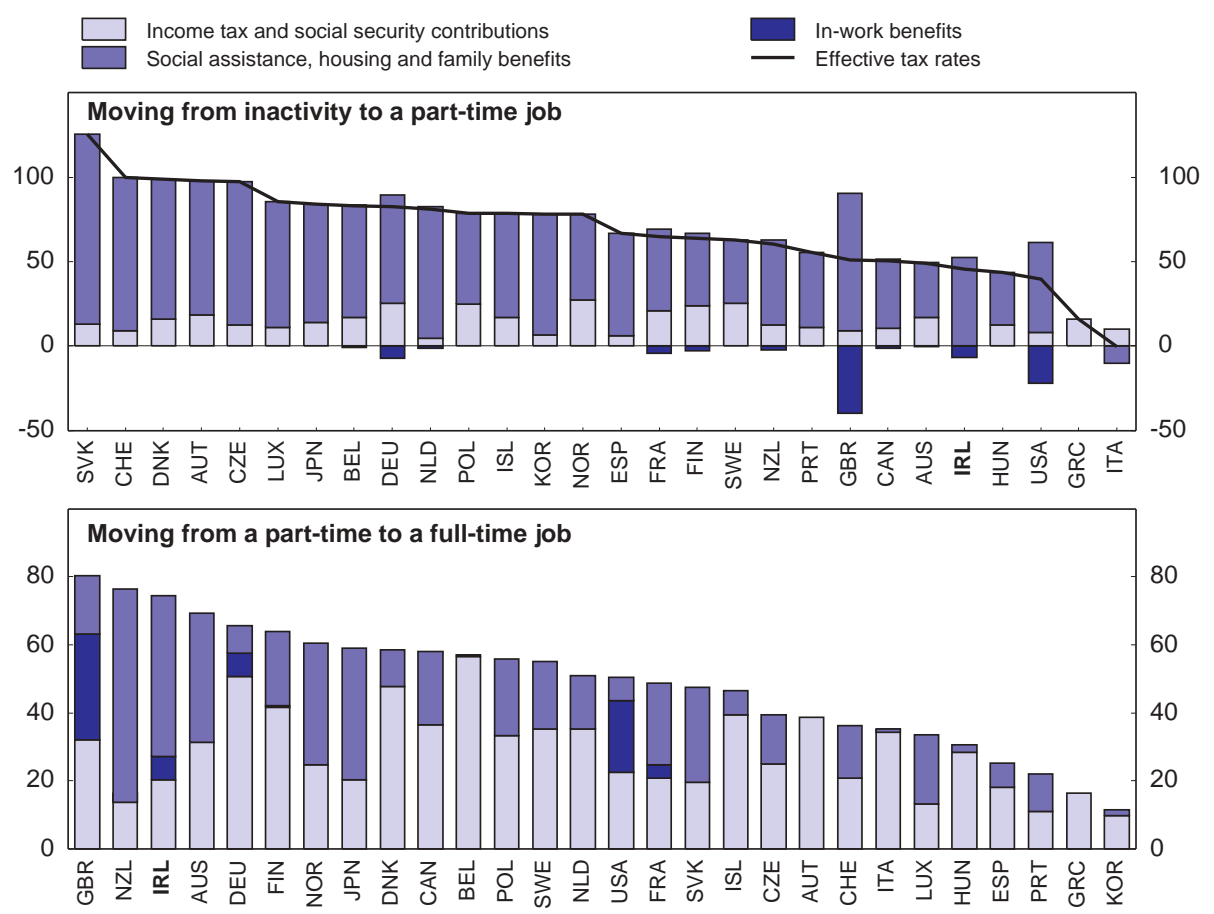

1. Part-time is defined as 20 hours of work per week at $50 \%$ of the salary of an average production worker (APW), full-time is defined as 40 hours of work per week at $100 \%$ of the APW salary. The graphs show how much of the increase in income following a move to part-time work from inactivity, or to full-time work from part-time work, is taken away in the form of higher taxes and lower welfare benefits.

Source: OECD (2005), Employment Outlook, Paris.

High marginal effective tax rates are an inevitable side-effect of any income-tested benefit and there is a trade-off between work incentives and the fiscal cost of income support. Helping sole parents regain a foothold in the labour market will require greater assistance by the government combined with stronger obligations on the individual:

- The government should improve active employment support such as assistance with finding work, preparing a $\mathrm{CV}$, etc.

- The implicit tax rate on work could be reduced by allowing sole parents to keep some of their benefits, including their medical insurance, for a limited time after they have gone back to work. The government could also introduce a time-limited back-to-work benefit, along the lines of Canada's experimental benefit for sole parents (OECD, 2003b).

- At the same time, job search requirements on sole parents whose youngest child is of school age should be strengthened. Ireland is almost unique now in having no job search requirement until children reach the age of 18 (or 22 if they are in tertiary education). Most other countries that had a similar system have moved away from it, realising that it is usually better for the children if their mother is in work, at least part time. However, the out-of-school care programme will need to be improved before work testing can be introduced. 
The design of the social assistance system also involves a poverty trap: lone parents gain very little from moving from part to full-time work at average levels of earnings. Amongst OECD countries, Ireland has one of the highest marginal effective tax rates on lone parents for the transition from part- to full-time work at the average production wage (Figure 4). The main reason is that the One Parent Family Payment is income tested with a fairly sharp phase-out rate (nearly 50\%). Other benefits, including the rent supplement and free medical care, are lost as well when moving to full-time work at average wage levels (OECD, 2003a). This poverty trap could be alleviated by raising the income threshold above which the One Parent Family Payment starts being withdrawn and by reducing the phase-out rate. Both measures would have to be implemented with care because they involve trade-offs: they have a fiscal cost and imply that marginal effective tax rates on lone parents will increase further up the earnings distribution.

\section{Gender pay differentials can also hinder female participation}

By reducing the return to work, lower pay for women can also depress female participation. Data for 2004 show women's hourly earnings are on average $18 \%$ below men's (CSO, 2004). The gender pay gap is very wide in high status occupations: women managers and senior officials are, on average, paid $28 \%$ less than their male colleagues. The difference is also large at the other end of the spectrum in elementary occupations, where women's hourly earnings are $25 \%$ below men's. Using individual-level data, Russell (2003) found that a great deal of the gender pay gap (40\%) cannot be explained by relevant labour market characteristics such as the number of years worked or out of the labour force and the level of educational attainment.

Anti-discrimination law could probably do more to reduce the pay gap. Using time series regressions, Cassidy et al. (2002) found that anti-discrimination legislation has had little effect on the pay differential. If established following an investigation by a specialised officer of the Labour Court, sex-based differences in pay do not subject offending employers to a fine but simply a non-binding recommendation to make pay equal. Against this background, use of the legislation has been very limited with on average only 23 individual recommendations issued annually. An avenue for improvement in this area would be to introduce fines set at a sufficiently high level to create an incentive for employers to refrain from sex-based differences in wages.

\section{Recommendations for sustaining growth in women's labour force participation}

The large increases in the number of women who joined the labour force over the last fifteen years have been a driving force behind Ireland's outstanding economic performance. Further reforms are needed to give all women a good chance to engage in paid work if they prefer to do so. Box 1 summarises the recommendations that would help progressing in this direction while preserving the social protection of women enshrined in the constitution. ${ }^{5}$ 


\section{Box 1. Summary of recommendations}

- Encourage county childcare committees and school boards to facilitate the provision of out-of-school-hours care in particular where existing school facilities are suitable or readily adaptable.

- Swiftly implement plans to increase the supply of training places for childminders.

- Over time, link childcare supports such as the Early Childcare Supplement to employment status or to the use of formal childcare.

- Phase out the Home Carer's Tax Credit.

- Give priority access to community childcare to working parents, especially lone parents.

- In order to reduce child poverty, provide job-search assistance and childcare support to lone parents. In return, boost job search requirements for lone parents on income support whose children are of school age. Consider allowing lone parents to keep some of their benefit for a limited time after going back to work.

- To encourage lone parents to take up full-time work, raise the threshold from which the One Parent Family Payment starts being withdrawn and reduce its phase-out rate.

- Continue to reduce average and marginal effective tax rates on second earners. To attain this objective and make the tax system simpler and more neutral, consider moving to individual taxation.

- Introduce fines for employers found in breach of Equal Pay legislation.

\section{Notes}

1. The OECD average and the figure for Ireland refer to a two-child family where both parents work and respectively earn $100 \%$ and $33 \%$ of the average production wage (APW). The Irish figure is for 2005. The OECD average is for 2001 and is taken from Jaumotte (2003).

2. The family is the same as the one described in note 1, with the extra hypothesis that the two children are below age six.

3. See Chapter 3 for a more detailed discussion of early childhood education.

4. The threshold is $€ 29400$ per year or $102 \%$ of the average production wage.

5. Article 41.2.2 states that "by her life within the home, a woman gives to the State a support without which the common good cannot be achieved" and that "mothers shall not be obliged [to work] by economic necessity." 
ECO/WKP(2006)39

\section{Bibliography}

Cassidy, M., E. Strobl, and R. Thornton (2002), "Gender Pay Differentials and Equality Legislation in the Republic of Ireland”, Canadian Public Policy, Vol. 28, Calgary, Alberta.

CSO (Central Statistics Office) (2002), "Household Composition and Family Units", 2002 Census, Vol. 3, CSO, The Stationery Office, Dublin.

CSO (2003), “Childcare”, Quarterly National Household Survey, Fourth Quarter 2002, CSO, Dublin, July.

CSO (2004), Men and Women in Ireland, CSO, Dublin.

Immervoll, H. and D. Barber (2005), "Can Parents Afford to Work? Childcare Costs, Tax-Benefit Policies and Work Incentives", OECD Social, Employment and Migration Working Papers, No. 31, OECD, Paris, www.oecd.org/els/workingpapers.

Jaumotte, F. (2003), "Labour Force Participation of Women: Empirical Evidence on the Role of Policy and Other Determinants in OECD Countries", OECD Economic Studies, No. 37, OECD, Paris.

McCreevy (2004), Testimony in front of the Select Committee on Finance and the Public Service during the debate on the Finance Bill 2004, 24 February, available from www.irlgov.ie/oireachtas.

National Women's Council of Ireland (2005), An Accessible Childcare Model, Dublin.

O’Connor, P. (1998), Emerging Voices: Women in Contemporary Irish Society, Institute of Public Administration, Dublin.

OECD (2003a), Babies and Bosses: Reconciling Work and Family Life, Vol. 2, OECD, Paris, www.oecd.org/els/social/familyfriendly.

OECD (2003b), OECD Economic Surveys: Canada, No. 14, OECD, Paris.

OECD (2005), Going for Growth, Economic Policy Reforms, OECD, Paris, www.oecd.org/eco/economicpolicyreforms 2005 .

Russell, H. et al. (2002), Getting out of the House: Women Returning to Employment, Education and Training, The Liffey Press, Dublin.

Russell, H. (2003), “The Gender Pay Gap", Mid-Term Evaluation of the National Development Plan, ESRI Policy Research Series, No. 50, Economic and Social Research Institute, Dublin, October.

Smith, N. et al. (2003), "The Effects of Taxation on Married Women's Labour Supply across Four Countries", Oxford Economic Papers, Vol. 55, Oxford University Press, July.

Tax Strategy Group (2004), Discussion Paper on Childcare, TSG-04/13, Department of Finance, downloaded from www.finance.gov.ie.

Whelan, C., B. Nolan and B. Maitre (2005), "Trends in Welfare for Vulnerable Groups: Ireland 1994-2001”, Policy Research Series, No. 56, Economic and Social Research Institute, Dublin, August. 
ECO/WKP(2006)39

\section{WORKING PAPERS}

The full series of Economics Department Working Papers can be consulted at www.oecd.org/eco/Working_Papers/

510. Assessing Russia's non-fuel trade elasticities: Does the Russian economy react "normally" to exchange rate movements?

(September 2006) Christian Gianella and Corinne Chanteloup

509. Regulation, competition and productivity convergence

(September 2006) Paul Conway, Donato De Rosa, Giuseppe Nicoletti and Faye Steiner

508. Improving education achievement and attainment in Luxembourg to compete in the labour market (September 2006) David Carey and Ekkehard Ernst

507. Raising economic performance by fostering product market competition in Germany (August 2006) Andrés Fuentes, Eckhard Wurzel and Andreas Reindl

506. Regulation of financial systems and economic growth (August 2006) Alain de Serres, Shuji Kobayakawa, Torsten Sløk and Laura Vartia

505. Enhancing Portugal's human capital

(August 2006) Bénédicte Larre and Stéphanie Guichard

504. Improving labour market performance in France Améliorer la performance du marché du travail en France (July 2006) Stéphanie Jamet

503. Wage setting in Finland: Increasing flexibility in centralised wage agreements (July 2006) Åsa Johansson

502. Regulation, competition and productivity convergence (July 2006) Paul Conway, Donato De Rosa, Giuseppe Nicoletti, Faye Steiner

501. The political economy of structural reform: Empirical evidence from OECD countries (July 2006) Jens Høj, Vincenzo Galasso, Giuseppe Nicoletti and Thai-Thanh Dang

500. Labour market performance, income inequality and poverty in OECD countries (July 2006) Jean-Marc Burniaux, Flavio Padrini and Nicola Brandt

499. Improving Public-Spending Efficiency in Czech Regions and Municipalities (July 2006) Philip Hemmings

498. Policies to Promote Innovation in the Czech Republic (July 2006) Alessandro Goglio

497. Getting Education Right for Long-Term Growth in the Czech Republic (July 2006) Alessandro Goglio

496. Assessing the 2005 Czech Proposals for Pension Reform (July 2006) Philip Hemmings and Edward Whitehouse

495. Poland's Education and Training: Boosting and Adapting Human Capital (July 2006) Paul O’Brien and Wojciech Paczynski

494. The Rates and Revenue of Bank Transaction Taxes (July 2006) Jorge Baca-Campodónico, Luiz de Mello and Andrei Kirilenko 
493. Nothing Ventured, Nothing Gained: The Long-Run Fiscal Reward of Structural Reforms (July 2006) Peter Hoeller and Claude Giorno

492. Ireland's Housing Boom: What has Driven It and Have Prices Overshot? (June 2006) Dave Rae and Paul van den Noord

491. Boosting Competition in Ireland (June 2006) Dave Rae, Line Vogt and Michael Wise

490. Factors Behind Low Long-Term Interest Rates (June 2006) Rudiger Ahrend, Pietro Catte and Robert Price

489. The Fiscal Challenge in Portugal (June 2006) Stéphanie Guichard and Willi Leibfritz

488. Are House Prices Nearing a Peak? A Probit Analysis for 17 OECD Countries (June 2006) Paul van den Noord

487. Maintaining Switzerland's Top Innovation Capacity (June 2006) Florence Jaumotte

486. Employment Patterns in OECD Countries: Reassessing the Role of Policies and Institutions (June 2006) Andrea Bassanini and Romain Duval

485. Brazil's Fiscal Stance During 1995-2005: The Effect of Indebtedness on Fiscal Policy Over the Business Cycle

(May 2006) Luiz de Mello and Diego Moccero

484. Realising the Oil Supply Potential of the CIS: The Impact of Institutions and Policies (May 2006) Rudiger Ahrend and William Tompson

483. Summary of a workshop on global convergence scenarios: structural and policy issues (May 2006) Nick Vanston

482. Revised OECD methods for supply-side and medium-term assessment: a capital services approach (July) Pierre-Olivier Beffy, Patrice Ollivaud, Pete Richardson and Frank Sédillot

481. Balancing health care quality and cost containment: the case of Norway (February 2006) Alexandra Bibbee and Flavio Padrini

480. The ageing challenge in Norway: ensuring a sustainable pension and welfare system (February 2006) Benoît Bellone and Alexandra Bibbee

479. Strengthening innovation in the Netherlands: Making better use of knowledge creation in innovation activities (February 2006) David Carey, Ekkehard Ernst, Rebecca Oyomopito and Jelte Theisens

478. How to sustain growth in a resource based economy? The main concepts and their application to the Russian case (February 2006) Rudiger Ahrend

477. Projecting $O E C D$ health and long-term care expenditures: What are the main drivers? (February 2006)

476. Alternative measures of well-being (January 2006) Romina Boarini, Åsa Johansson and Marco Mira D'Ercole 